\title{
Editorial
}

\section{A vitória do Sinam}

“Vencer não é tudo. É mais do que isso."

(Vincent Lombardi)

Queos nossos esfor ços desafi em as impossibilidades, dizia Charles Chaplin. Nessa linha de pensamento, oSinam representou, desde o seu lançamento, um grande desafio. Com certeza, teríamos que enfrentar resistências e dificuldades de todas as formas. Mesmo assim, aceitamos e partimos para o "bom combate".

Agora, ao ver o Sinam completar seu primeiro aniversário, já nos sentimos realizados. Em tão pouco tempo, deixou de ser um horizonte para transformar-se numa das maiores conquistas da classe médica. O Sinam é hoje uma realidade extremamente grati ficante que não tem mais vol ta. Caminha inexoravel menteem busca do seu grande destino.

De nada adiantou alguns colocarem a política, a inveja, os interesses pessoais frente ao Sinam; ele passou por cima de tudo e de todos. Aquel es que simplesmente criticaram, sem apresentar uma alternativa melhor, terão quesecurvar diante desta granderealidade.

Praticamente, já concluímos a fase de implementação do Sinam em todo o País. I niciamos, agora, o processo de descentralização para as F ederadas que desejarem assumir a coordenação dosistema em seus E stados. Daremos todo o apoio logístico, técnico e de material. As F ederadas do Paraná, Rio Grande do Sul, Bahia e Alagoas já o fizeram.
Só seremos fortes e conseguiremos vencer a submissão que nos i mpõe o atual si stema alternativo de saúde quando o funcionamento do Sinam, em nível nacional, estiver consolidado sob um só pensamento. Para tanto, é necessári o que estejamos unidos em torno do projeto, mesmo dentro de algumas divergências.

Cabe-nos aqui lembrar as palavras queo ilustre col ega J úlio Sanderson, brilhante orador, costuma dizer quando, diante de uma crise, compara os médicos aos metalúrgicos. Depois de algumas consi derações enfatiza: os metalúrgi cos são uni dos mesmo em se odiando. E conclui: e os médicos? Os médi cos são desuni dos mesmo em seamando. Porém, a crise que estamos vivendo trouxe uma nova e grande bandei ra de luta - oSinam. E éel equevai unir os médicos em todo o Brasil.

Mas o que vale neste momento é que o Sinam está indo maravilhosamente bem. Mais de 300 mil inscritos. A população está satisfeita e os profissionais escolhidos livremente começam a atender seus pacientes, recebem diretamente sem intermediários, sem qualquer taxa de administração. É apenas o médico e seu paciente, ninguém mais. O que seria apenas um sonho, mas que agora sonhado por todos, tornou-se realidade. Parabéns a todos pelo "sistema dos médi cos"!

\section{Antonio Celso Nunes Nassif}

Presidente da AMB 